\title{
Minimalism in Literature - Musine Kokalari
}

\author{
Meliza Krasniqi \\ Ph. D. Cand. Scientific Researcher, Literature \\ South East European University, Institute of Albanology - Prishtina
}

\begin{abstract}
Musine Kokalari is first Albanian prose writer, who in 1941 was awarded the "Doctor of Literature" by the University of Rome. She started her literary creation with poetry and literary outlines published in newspapers and magazines of the time, also publishing within a few years the books "Siç më thotë nenua plakë" (1939), "...sa u tunt jeta" (1944) and "Rreth vatrës" (1944). In the summer of 1939, Musine wrote the prose "Siç më thotë nenua plakë", published in September of that year in the printing house "Gutenberg" in Tirana. Kokalari's work is dedicated to the world and spirit of women. Through her stories she builds the identity, discourse, psychology, fate and misfortune of women. Characters and the narrator are women. These ten texts are closely related to each other, thematically, structurally and formally. In this paper we strive to determine the minimalist form of these proses that emerge through a sui generis artistic narrative.
\end{abstract}

Keywords: Albanian literature, prose, minimalism, Kokalari, small worlds

\section{Introduction}

Musine Kokalari is a Western-type Albanian intellectual, who in 1941 was awarded the "Doctor of Literature" by the University of Rome, for her thesis: Albanian Literature-Naim Frashëri. Musine was one of the few to have completed her undergraduate studies, and was a bright and smart girl with broad interests. She started her literary creation with poetry and literary outlines published in newspapers and magazines of the time, also publishing within a few years the books "Siç më thotë nenua plakë" (1939), "...sa u tunt jeta" (1944) and "Rreth vatrës" (1944). Kokolari is one of the rare women who kept writing between the two wars in the period 1912-1945. The figure of Musine Kokalari represents not only the fate of Albanian women intellectuals, but also the first Albanian woman politician and writer.

Learning that Musine Kokalari was the first female writer in Albania, and the only one until the 1960s, today she is the symbol of a woman intellectual who introduced a new development in the modern Albanian literature, unseen before.

\section{Scope}

In the summer of 1939, Musine wrote the prose "Siç më thotë nenua plakë", published in September of that year in the printing house "Gutenberg" in Tirana. This seemingly modest work ( $80 \mathrm{p}$.) is made of ten prose pieces, classified into tales of youth (Elsie, 1997, p. 241) novels (Kokalari, 2009, p. 354), literary outlines (Poradeci, 1940) (as were called at the time) or stories.

Musine Kokalari stands out as a literary phenomenon in prose (Hamiti, 2009, p. 428) introducing thematic, technical and stylistic innovations to Albanian literature, thus bringing original creations. Courageous in life, she comes as a writer of literary experiments at the time when Albanian literature had big names of prose in Koliqi, Kuteli, Migjeni, Spasse, Stërmilli, etc.

This time of literary writing, later to be called "literature of the period of independence-invasion 1912 (1924) - 1939 (1944) (Pipa, 2013, p. 187/188)" or "literature of the period 1940-45 (Hamiti, 2009, p. 425)" produces an author/subject who writes texts that target the world of Albanian women and which brings woman into focus in all her writing activities. Kokalari's work is dedicated to the world and spirit of women. Through her stories she builds the identity, discourse, psychology, fate and misfortune of women. Characters and the narrator are women. These ten texts are closely related to each other, thematically, structurally and formally. 
In this study we strive to determine the minimalist form of these proses that emerge through a sui generis artistic narrative.

\section{Minimalism (in literature)}

Minimalism in literature is a phenomenon that is not related to a specific literary trend or school. The term "minimal" as the root of the word "minimalism" in Albanian is defined as: the smallest or the lowest among others at a certain scale, of a lower level or of a lower threshold; small, low and that it cannot get smaller or lower. In this sense, minimalism seeks the smaller in politics and art and this is achieved in different ways and at different levels.

In politics, minimalism was used in the early 20th century, more specifically according to the English Oxford Dictionary, the first use was made on 18 October 1906 (Dictionary, 2005) while its application in art was made later. Critics of visual art and minimalism music are describe it as the technique of "undressing" (simplification) of the work so that viewers and listeners concentrate on the most important and essential elements of the work.

In literature in the early 1900s writers like Ezra Pound, Gertrude Stein, Francis Scott Fitzgerald, and above all Ernest Hemingway, used the minimalist style in their works. Hemingway stories, such as: Cat in the Rain, and the Hills Like White Elephants were not considered minimalist until the 70 s, when authors like Raymond Carver were influenced by this writing type. This fact underlines that minimalism, as an approach and style, does not appear in any single period and cares not whether the text is old or new. In this spirit, we can say that regardless of where literature is developed, there is a minimalist tendency because it is timeless.

Given the principle of searching for the small, simple and minimal form, minimalism is discovered and tried in two levels, in the outer and inner structures of literature. According to John Barth in "A Few Words About Minimalism (Barth, 1986, pp. section 7; p. 1, column 1)," there is minimalism of the unit, form and scale: short stories, short sentences and paragraphs. Minimalism in style: simple and straightforward vocabulary; common syntax; rhetoric with minimal figures without decorations and formal complications; non-emotional tone; and minimalism in the subject: characters, description, presentation, action, intrigue.

In terms of general criteria we notice that the most distinctive features of a minimal text are:

an open, simple, clear story;

the story begins in medias res without previous descriptions

a story that starts from a particular (situation or a particular character) to a more complex (typical) model;

these stories are dominated by dialog rather than a description without interference of the narrator;

characters are not heroes, they resemble ordinary people in everyday life;

the story creates the feeling that the "action" has taken place long ago, or a few moments before the story begins, or that it will happen later, meaning that it does not happen during the narration.

In Albanian studies, the phenomenon of minimalism has never been addressed, although the poetics of short stories during the 1930s shows that this type of writing had also affected the Albanian literature. According to critical studies and writings for this period, it is understood that short story was the most popular and the preferred form of the time (Aliu, 1975, pp. 6171). Writers such as Migjeni, Nonda Bulka, Petro Marko and Andrea Varfi, tried in their works to achieve an expressive communication and quick response to everyday problems. The principle, in most cases, this was done in a: simple, short and clear form. The text had no room for "big chunks of life (Qosja, 1968, p. 208)" but the indulged the short, clear-cut view, and the expression was undressed (bare). Another characteristic of the story was it went straight into the topic "with short, laconic and straightforward phrases (Gurakuqi, 1966, p. 246)" without any rhetoric, with few figures "often receiving the hues of a free conversation with the reader. (Eshrefi, 1990, p. 32)" In little text, that often included no more than two pages, they expressed emotional feelings and emotions, presented the environment and the timid atmosphere of the time but failed to create types and characters. The narrator's function in this prose is realized by the main character, namely the homodiegetic narrator. In the end, this form is interwoven with elements of drama, usually through dialogue and the monologue, while the actions, of characters' steps or hands match the tempo of action films. 
This creative spirit and practice of short stories in the 1930s is identified with the minimalist phenomenon in many varieties of texts of Migjeni, Nonda Bulka, Petro Marko, and Adrea Varfi, as an internal characterization especially when we recall that minimalism and realism are close relatives. Such signs of form and structure simplification are also tested by Kokalari, who writes this contemporary form in a more perfectly formalized plan.

\section{Musine Kokalari's minimalism}

At this point, we believe that her work "Siç më thotë nënua plakë" contains the fundamental and determining characteristics of minimalism. Everything begins with the piece by Lasgush Poradec, who, evaluating Kokalari's short stories as original creations with a new substantial style, among other, says: With such precise observation, full of liveliness and freshness, are these miniatures of Musine Kokalari! (Poradeci, 1940, pp. 6-7) Pogradeci sees the fictional works of these ten texts and their inner dramatics as miniature. These are the first important signs that uncover the essence of Kokalari's bibliography. Indeed, minimalism is not miniaturism, however the criterion of small, as the basis upon which the texts are built, is problematized. Kokalari had jumped over the level of miniaturistic narrative with the publishing of poetry and literary outlines in the press and literary periodicals, later under the title of "Kolla e vdekjes". Meanwhile, we will take this idea a step further to argue that the stories of Kokalari are narrations that challenge miniaturism by filling it with minimalist elements.

In "Small Worlds" Warren Motte (Motte, 1999) speaks of the minimalist writers who, according to him, choose to address and concentrate on "simple" things in their works, through direct intrigue, ordinary characters, and even laconic dialogue between characters, etc.

Kokalari is not exclusively a minimalist writer, however she uses a number of minimalist techniques that are out in plain sight in every search/reading. From the nature of the economy of the text, she makes aesthetics of stories that begin in the media res and continue with a powerful dialogue and revolve with a large number of repetitions from the homodiegetic narrative voice. Its minimalist writing becomes representative through a special structural and contextual model.

At first glance these short stories seem to lack the essential elements of a story, but in accordance with the minimalist narrative, each word is essential. The importance of these characteristics is different and we will present the premise as prevailing signs of the form.

Minimalism authors carefully choose the words and allusions where the form follows the function. The title "Siç më thotë nënua plakë (As the old mother tells me)" mentions the name and image of the "old mother" that marks the broken age, the experience with an emphasis on the gender principle. This scheme extends as a model for the ten stories as each text includes the woman as the primary and secondary characters. Naturally, because most of them are narrated from women characters, the perspective of Kokalari is feminine. In the diary "Jeta ime universitare (My University Life)" the author subordinates this fact by saying that she wrote ten novels "where life, thoughts, pains, superstitions and miracles of these people (women) (Kokalari, 2009)" and continues "I ran to my mother and read her the writing for her to corrent me", thus constructing and preserving the unifying perspective in all the texts - the elder mother, namely the woman.

The discourse of Kokalari is also revealed in the word tells (as [Old Mother] tells me...) which refers denotatively to the oral narration. Why did the writer need to allude to the told words of the mother, in the very title? Because by giving the model (tells) in the title, she makes her the discourse and the subject of the outline. The discourse of narratives is simple, conversational, as of (older) mothers. Kokalari takes care not to "risk" this discourse. Whereas the tense, as we have already mentioned, is the present "As [Old Mother] tells me" - now/presently.

In the introductory paragraphs of all stories, a text with a declarative and direct tone is forewarned:

Lermë biro, mos më mer mënden, mos më rokanis ${ }^{1}$ mos më shkul zorët. E ç'të lipsen se si rronim ne? Pse, apo të qeç. Se ç'u bëmë ne, nuk jua kemi zënë sinë, apo mos ju prishmë hundën?

(Siç më thotë nënua plakë)

- More në dalça jashtë, dhe në të zënça dot, pa më sheh mua se ç'do të të bëj, të kam për të marë shpirtin more zabërhan²

\footnotetext{
${ }^{1}$ Rokanis $=$ grind

2 Zabërhan = rrugaç
} 
(Për mustaqet e Çelos)

- Ti, ja ke hipur kalit, prandaj më flet kështu moj Aishe. Je me burrë vetëm dhe e bën si të duaç, pastaj e ke të mbledhur, nuk është i prishur ${ }^{1}$

(Është e thellë)

Kokalari does not use referral titles, "she said" or "he said" in the dialogue. This stylistic choice is a sign of a strategy that suggests creating a sense of the likelihood that "she said", and "he said" are unnecessary and hence abandoned. This falls in line with the minimalist "definition" and applies for the structure of all stories.

The texts are developed only by two or three characters (grandmother/niece, two neighbors, two sisters-in-law, two sisters, mother/daughter, mother-in-law/bride, two friends) which are sometimes named. For example, in the first story and the story "Udhen e mbare paste", the characters have no names. The grandmother's figurerepresents the old, the past mindset and worldview, and takes the paradigm of the universe of the past and conservatism, whereas the niece represents the daughters, the brides, she is the model of the new, related to the future and progress. We never learn the age of the characters, their appearance, profession, form, status or any other personal details. We find their characterization in actions, dialogues, and sometimes from harsh thoughts as is commonly the case in minimalist writings. The characters of Kokalari are an image of the type of people she knew best belong to the middle class or the poor. In the story of "Për mustaqet $e$ Çelos", the character of Merusha steals the chickens of the neighborhood while in "Udhën e mbarë pastë" the boy flees the country because they are light and thin thus showing us in different forms their financial struggles. The fictional world of Kokalari is "populated" with elderly women, married women and widows, unmarried girls, thieves, housewives, migrants and the like who are struggling to face the challenges of everyday life such as death, sickness, poverty, divorce, marriage, loss, lack. The author chooses and distinguishes two to three features of her characters that are simplified and sometimes transformed into caricatures and undoubtedly two-dimensional characters. Characters appear as the emotional and psychological "landscapes" of people between the two World Wars.

The status of "simple characters" of Kokalari who discuss and quarrel for simple stuff is typically minimalistic for other reasons as well. They reside in suburban neighborhoods made up of houses of similar architecture, living with almost the same difficulties and problems. In terms of the location, the stories are placed in small environments and indoors, usually in living rooms, bedrooms, kitchens. This is a familiar topos of minimalist art. Characters in Kokalari's minimalist stories often appear to be doing house chores or drinking coffee and discussing things that are, seemingly, irrelevant. The things mentioned increase the meaning and create a sense of reality. Thus, it is perfectly possible for the stories to write about common things and objects using common languages and giving these things - pots, cups, plates, table racks, bread, underpants, socks, shirts, t-shirts, coats, pots, meat - significant, even surprising, power. In each story, the characters interact through trivial things such as, most frequently, drinking coffee, but other other common occurrences as well such as washing the dishes in the kitchen, preparing lunch/dinner, going or coming to visit, etc. thus the minimalist texts place the emphasis clearly on the direct experience to state the nature of reality.

Musine had spent her childhood in Gjirokaster and her writing is linked to this environment, but her stories never explicitly give the name of the country or the city. Her position is sincere, whereby through such a structurally simple fiction, she characterizes the mentality and moral state of a time and a country, Albania in the 1930s, or more specifically Gjirokaster. She tries to develop the minimalist conventions with a discourse that exactly captures the daily reality of the country and the time, and thus the work portrays "its time". Kokalari makes a double "play" with the language used in stories, with a Toske variety. The language of the old mother makes an aesthetic principle to "tell" the language of the place. Perhaps it would have been simpler if the author would directly identify the place, but she leaves with the implication that it is Gjirokaster. She deliberately imitates and preserves, with a meticulous dialogic process, the idiom in order to give social construct. The model of such discourse is an additional characteristic feature of the minimalist style, often involving strange and humorous expressions, to characterize serious topics addressed in stories. Kokalari created a variant of the biography of Gjirokastra through simple and direct language to give the place a factual look. She avoids referencing to authors such as Koliqi and Migjeni who connect with the environment of Shkoder and wrote in a language and discourse immersed in figures.

\footnotetext{
${ }^{1}$ Prishur $=$ njeri që prish pa mend, së koti
} 
Kokalari, although in her forming stage in the minimalist aesthetic of stories, she used the technique of repetition as a procedure that suits rather well to the genre of short stories. The best example of repetition can be found in the story "Paç fatin e të ligavet (May you have the fate of the wicked)", where the variation of repetition as a tool comes to words, phrases, ideas and motives. The "wicked" subject is revealed in the title and through dialogue because description is conditional here as well. The homodiegetic narrator, present as grandmother's character, repeats the word "wicked" to make known the state of the niece who misses on the opportunity to marry a good boy and reveals the character of the other, who caught this chance. The word "wicked" defines "bad" in all its dimensions, as a fortune, as a characterization, and as a view that relates to the conjunction of events of chance that happen in someone's life as "bad luck". The wicked fate, may you have the fate of the wicked, the wicked, far from the wicked, the worse of all wicked, are woven through expressions such as donkey, slut, ugly, Arab, etc. The situation of the wicked, the position of the wicked, and other formulations refer to life and the reality of the wicked.

Thuaj si të duaç, shikoju fatin që kanë. Të liga si ato, të prapa jashtë udhës, golë-shporta, gjuhën sa një lopatë, maruka1 të grisura nga mënt e kokës, fëllega² që kur hin në shtëpin' e tire të zëq hundët.

Kokalari texts have quick, sometimes rebellious and honest rhythm. The author begins the narration without a forewarning, they are "open" and readable, with the immediate introduction, without representations and descriptions. The writing has an occasionally satiric tone, with a hint of humor.

To further characterize minimalism, the author chooses the extradiegetic and intradiegritic story and a heterodiegetic, homodiegetic and autodiegetic narrator.

U-ulnë të dija mbi çilte, e pjeti dhe Xhevrua na ana e saj. Ishin di shoqe që të jetës. Ishin martuar, me një grikë fëmile dhe dashurin' e parë s'e kishin harruar. Razos I gëzohej shpirti që Xhevrua e kish nusen të mirë, pastaj ja kish bërë vetë krushqinë.

(Një qen që hamullit nuk ha)

Eh! Që më hangri, që s'i pushoi birbili. ${ }^{3}$ Nuk durohet dhe kjo, s'kam parë një ditë të bardhë, që kur kam kallur këmbët në këtë të zezë gërmadhë - qahej Durijeja për vjehrën e saj Fatimenë.

(Mos qofshin vjehrat e zeza)

\section{Conclusion}

Minimalism of Kokalari has many corrugations, crafts and synthesis. She adheres to an order of denominators as components of the inner structure. Her stories are "pieces of life" that show the basic elements of everyday life; the environment of the story is generrally a common household; nonfromal and conversational tone; stories capture the main lines of life without being caught in detail; literary expressions are bellectristic, leaving signs of implication; thoughts and feelings are not expressed until the end but are also implied; characterism is used instead of describing characters; the sentence structure is simple, figurative language reduced with the repetition of few words and phrases; narration is in the present tense with dense dialogue; stories have no solutions, the conclusions are left open.

The prose "Siç më thotë nënua plakë," which gave Kokalari the epithet of the first woman author to publish a book, introduced novelties in Albanian literature. The author had made a step in the experimental aesthetic path in her formation as a writer. She tried to develop a discourse that captured with precision the daily reality of a country, at one time referring to the subject and the world of women. The structure of the work of Kokalari can be considered to be aesthetic because it subject to the shape that takes the look of a minimalist mosaic.

\footnotetext{
${ }^{1}$ Maruka = e marrë

2 Fëllega = të ndotura, të papastra

${ }^{3}$ Birbili $=$ (metaf.) gjuha, të folurit
} 


\section{References}

[1] Aliu, A. (1975). Short Prose as the Determined Consciousness of Time - Time and Creator. Prishtina: Rilindja.

[2] Barth, J. (1986). A few words about minimalism. New York: www.nytimes.com.

[3] Dictionary, T. O. (2005). The Oxford English Dictionary. OED Online: Oxford University Press.

[4] Elsie, R. (1997). History of Albanian Literature. Tirana-Peja: "Dukagjini" Publishing House.

[5] Eshrefi, I. (1990). POetry of Social Literature of the 30s. Prishtina: Rilindja.

[6] Gurakuqi, M. (1966). Authors and Problems of the Albanian Progressive Literature of the 1930s. Tirana: "Naim Frashëri".

[7] Hamiti, S. (2009). Modern Albanian Literature. Tirana: UET/Press.

[8] Kokalari, M. (2009). My University Life. Tirana: "Geer".

[9] Motte, W. (1999). Small Words - Minimalism in Contemporary French Literature. USA - Nebraska: University of Nebraska Press, Lincoln and London.

[10] Pipa, A. (2013). Albanian Literature: Social Perspective. Tirana: Botimet Princi.

[11] Poradeci, L. (1940). Siç më thotë nënua plakë. Korçë: "Bota e re" No. 1/30.

[12] Qosja, R. (1968). Dialogue with Writers. Prishtina: Rilindja. 